\title{
EFFECT OF WORK STRESS AND WORK SATISFACTION OF EMPLOYEES PERFORMANCE PT. PRIMATAMA MULIA JAYA IV KOTO KINALI KECAMATAN KINALI KAB. PASAMAN BARAT
}

\author{
Frencus Samosir, Maria Magdalena \\ Sekolah Tinggi Ilmu Ekonomi "KBP"
}

\begin{abstract}
The purpose of this study to determine and analyze the influence of job stress and job satisfaction partially and simultaneously to the performance of employees of PT. Primatama Mulia Jaya IV Koto Kecamatan Kinali Kab. Pasaman Barat. The research method used is quantitative descriptive. The sampling technique used is accidental sampling method so that from the population is taken as many as 73 respondents, the data collection method used is by using survey or observation, questionnaire and literature study. Data analysis techniques used were classical assumptions, multiple linear regression, $t$ test, $F$ test and detemination coefficients. Based on multiple regression analysis, work stress variable and job satisfaction on employee performance in get $Y=18,776+0,510 X_{1}+0,156 X_{2}+e$. From the t test conducted got job stress and job satisfaction have a significant and positive effect on employee performance of PT. Primatama Mulia Jaya IV Koto Kecamatan Kinali Kab. Pasaman Barat From the results of $F$ test proved that the variable of work stress and job satisfaction simultaneously have a significant and positive effect on the performance of employees of PT. Primatama Mulia Jaya IV Koto Kecamatan Kinali Kab. Pasaman Barat, while the result of coefficient of determination obtained ability of independent variable explain dependent variable equal to $36,9 \%$ rest $63,1 \%$ explained by other variable not used in this research.
\end{abstract}

Keywords: Job Stress, Job Satisfaction and Employee Performance.

\section{Latar Belakang}

Pengelolaan SDM dalam suatu industri bertujuan supaya dapat mengembangkan suatu keahlian terhadap SDM agar terjadi peningkatan kinerja. Kinerja yaitu suatu hasil kerja dari seseorang yang terorganisir kedalam kelompok. Kinerja karyawan yang tinggi akan memberikan manfaat positif bagi organisasi sehingga manajemen dalam organisasi berupaya mengelola sumber daya manusia yang sebaik-baiknya.

Dalam kehidupan yang canggih makin kompleks, individu biasanya mengalami tekanan apabila dia kurang bisa mengadaptasikan suatu kemauan dengan kenyataan yang ada. Baik fakta yang ada didalam maupun diluar dirinya, segala macam tekanan pada intinya dikarenakan oleh kurang pahamnya individu terhadap keterbatasannya. Ketidaksanggupan untuk melawan keterbatasan akan menimbulkan suatu konflik, kuatir, kekecewaan, yang merupakan tipe-tipe dasar dari tekanan (Luthan, 2006: 439).

Stres yang dialami oleh pegawai akibat dari lingkungan yang dihadapinya akan mempengaruhi prestasi dan kepuasan kerjanya, sehingga manajemen perlu meningkatkan mutu lingkungan organisasional bagi pegawainya. Dengan menurunnya stres yang dialami karyawan tentuakan meningkatkan kesehatan dalam tubuh organisasi. Stres yakni suatu perihal dimana individu dihadapkan pada konfrontasi antara kesempatan, hambatan, atau permintaan akan apa yang akan diinginkannya dipersepsikan tidak jelas dan signifikan.

Stres kerja yang ditata dengan bagus memungkinkan buruh untuk menjangkau kinerja yang sangat optimum. Individu memerlukan stres kerja sebagai pendorong 
individu dalam memenuhi tuntutan lingkungan, selama individu dapat mengelola kondisi streskerja maka individu tersebut akan mendapatkan manfaat dalam pencapaian kinerjanya. Stres kerja dalam waktu cukup lama dengan beban stres yang cukup besar akan menjadi penyebab penurunan kinerja.

Karyawan akan memberikan kemampuan yang dimilikinya secara maksimal dalam bekerja ketika karyawan merasa mendapatkan timbal balik berupa kepuasan kemampuan kerja yang diberikan secara sadar akan mendorong peningkatan kinerja karyawan kepuasan yang diperoleh oleh seorang karyawan yang didukung oleh kemampuan lingkungan kerja dalam menanggapi pekerja demi sumber daya yang paling bermakna dalam lembaga. Manajemen organisasi menggunakan agar terpenuhinya kondisi kepuasan kerja karyawan sebagai alasan untuk meminta timbal balik berupa pencapaian kinerja.

Kepuasan kerja harus diciptakan sebaik-baiknya agar etika kerja, pengabdian, kecintaan dan kedisiplinan kerja tinggi. Menurut Luthan (2006 : 243) mengemukakan bahwa kepuasan kerja yaitu situasi emosi yang senang atau positif yang bersumber dari evaluasi suatu pekerjaan terhadap keahlian kerja individual.

PT. Primatama Mulia Jaya IV Koto Kecamatan Kinali Kab. Pasaman Barat yaitu salah satu industri yang bergerak dibidang perkebunan kelapa sawit serta mempunyai loyalitas untuk mengembangkan kemampuan usaha serta kesuksesan yang menyeluruh serta menciptakan lingkungan, yang mengharuskan bagi para pekerja dalam mengembangkan kemampuan yang mereka miliki untuk mencapai aspirasi pribadi mereka masing-masing. PT. Primatama Mulia Jaya IV Koto Kecamatan Kinali Kab. Pasaman Barat selalu melakukan perubahan arah pada perusahaannya yang mengakibatkan organisasi manajemennya juga berubah.

Berdasarkan pertanyaan yang diekspresikan di atas maka peliput narator tertawan ingin melakukan tentang adanya sebuah observasi tentang "Pengaruh Stres
Kerja dan Kepuasan Kerja Terhadap Kinerja Karyawan PT. Primatama Mulia Jaya IV Koto Kecamatan Kinali Kab. Pasaman Barat".

Rumusan Masalah

1. Apakah Stres Kerja berpengaruh terhadap Kinerja Karyawan PT. Primatama Mulia Jaya IV Koto Kecamatan Kinali Kab. Pasaman Barat?

2. Apakah Kepuasan Kerja berpengaruh terhadap Kinerja Karyawan PT. Primatama Mulia Jaya IV Koto Kecamatan Kinali Kab. Pasaman Barat?

\section{Tujuan Penelitian}

1. MenganalisisPengaruh Stres Kerjaterhadap Kinerja Karyawan PT. Primatama Mulia Jaya IV Koto Kecamatan Kinali Kab. Pasaman Barat.

2. MenganalisisPengaruh Kepuasan Kerjaterhadap Kinerja Karyawan PT. Primatama Mulia Jaya IV Koto Kecamatan Kinali Kab. Pasaman Barat.

\section{TINJAUAN PUSTAKA}

\section{Stres Kerja}

\section{Pengertian Stres Kerja}

Menurut "Beehr dan Newman dalam

Luthans (2006)" menjelaskan bahwa stres kerja ialah suatu suasana yang muncul dari hubungan antara individu dengan pekerjaan dan dikarakterisasikan oleh perubahan individu yang memaksa mereka untuk beralih arah dari kegunaan normal mereka". Menurut studi Soesmalijah Soewondo (dalam Devi S, 2003:19) menjelaskan bahwa stres kerja yaitu kondisi dimana terdapat satu atau setengah dampak lokasi kerja yang bereaksi dengan karyawan sehingga dapat mengganggu kondisi perilaku (fisiologis), serta tekanan kerja akan timbul apabila terdapat jarak antara kemampuan individu dengan tuntutan-tuntutan dari pekerjaannya. Stres yaitu jarak antara kebutuhan seseorang dengan pemenuhannya dari lingkungan.

\section{Indikator Stres Kerja} Indikator stres kerja menurut Robbins (2008), dapat dibagi dalam 3 aspek, yaitu :

1. Indikator aspek pisikologis yaitu banyak menghayal, lemah intelektual, 
mudah sakit hati juga kurang komunikatif.

2. Indikator aspek fisik ialah mudah letih secara jasmani, problem dalam tidur terkadang kebanyakan atau mengalami kekurangan tidur, sakit kepala, serta meningkatnya darah tinggi sehingga bisa menimbulkan tekanan jantung getaran yang tidak stabil.

3. Indikator aspek sikap ialah menunda atau menjauhi segala aktivitas, pola makan yang tidak teratur, merokok yang melebihi batas dan perilaku perusakan.

Kepuasan Kerja

Pengertian Kepuasan Kerja

Menurut Wagner III \& Hollenbeck (dalam Dhania 2010:16), mengutip ungkapan yang diberikan oleh Locke, yang menjelaskan kepuasan kerja adalah suatu perasaan menyenangkan yang datang dari dugaan seseorang mengenai pekerjaannya/yang lebih penting. Menurut Davis dalam Mangkunegara (2013:117), menjelaskan bahwa kepuasan kerja ialah kemurahan hati dan aktivitasnya sangat menguntungkan bagi karyawan.

\section{Indikator Kepuasan Kerja}

Ada lima indikator penentu kepuasan kerja yang disebut dengan Job Descriptive Indeks (JDI) (Luthans, 2006 dan Robbins, 2003), yaitu :

1. Kawan Kerja

Kebutuhan dasar individu untuk melaksanakan ikatan sosial akan terpenuhi dengan adanya kawan kerja yang mendukung pekerja.

2. Pekerjaan sendiri

Fase dimana sebuah akttivitas menyediakan harapan untuk belajar dan fungsi yang menyenangkan serta kesempatan untuk mendapatkan tanggung jawab.

3. Pengawasan/supervisi

Kemampuan supervisor untuk mempersiapkan bantuan teknis dan perbuatan dukungan.

4. Kesempatan/Promosi

Pegawai mempunyai harapan untuk mengelaborasikan serta memperlapang pengalaman kerja dengan terbukanya kemungkinan untuk kenaikan kedudukan.
5. upah

Menurut penelitian "Theriault" kepuasan kerja adalah derajat sejauh mana upah untuk mencukupi segala harapan- harapan tenaga kerja serta bagaimana upah diberikan guna dari jumlah "absolute" dari upah yang didapat, upah atau gaji diakui merupakan dampak yang signifikan terhadap kepuasan kerja.

\section{Kinerja Karyawan}

\section{Pengertian Kinerja Karyawan}

Mangkunegara (2005: 67)" yaitu hasil kerja secara kuantitas dan kualitas yang digenggam oleh buruh dalam melakukan kesibukannya sesuai dengan kewajiban yang telah diberikan kepada buruh tersebut.

Menurut "Kusriyanto dalam Mangkunegara tahun 2005:9 mengartikan bahwa kinerja yakni kombinasi konsekuensi yang diperoleh dengan peran serta buruh sebagai gabungan dari waktu.

\section{Indikator Kinerja}

Menurut Simamora (2004), diukur dengan indikator-indikator sebagai berikut:

1. Kuantitas hasil kerja, yaitu meliputi jumlah produksi kegiatan yang dihasilkan.

2. Kualitas hasil kerja, yaitu yang meliputi kesesuaian produksi kegiatan dengan acuan ketentuan yang berlaku sebagai standar proses pelaksanaan kegiatan maupun perencanaan suatu kelompok.

3. Ketepatan waktu penyelesaian pekerjaan adalah untuk pemenuhan kesesuaian waktu dengan yang dibutuhkan serta diinginkan dalam pelaksanaan suatu aktivitas.

\section{Hipotesis}

1. Diduga stres kerja berpengaruh yang signifikan terhadap kinerja karyawan pada PT. Primatama Mulia Jaya Wonosari Kecamatan Kinali Kab, Pasaman Barat.

2. Diduga kepuasan kerja berpengaruh yang signifikan terhadap kinerja karyawan pada PT. Primatama Mulia Jaya Wonosari Kecamatan Kinali Kab, Pasaman Barat. 


\section{METODE PENELITIAN}

\section{Populasi dan Sampel}

Menurut "Ferdinand (2006)", mengartikan bahwa populasi ialah himpunan atau seluruh dari bagian objek studi yang menguasai karakteristik yang sama dan yang menjadi pusat ketertarikan seorang pengkaji. Populasi dalam penelitian ini adalah 267 orang karyawan.

Menurut Ferdinand (2006), sampel adalah sebagian dari jumlah populasi yang dapat mewakili berjalannya suatu penelitian yang memiliki karakteristik sesuai dengan penelitian yang akan dijalankan oleh sipeneliti. Adapun sampel penelitian ini adalah sebagian karyawan PT. Primatama Mulia Jaya Wonosari Kecamatan Kinali Kab. Pasaman Barat. Untuk menentukan jumlah sampel yang diperlukan, maka dapat digunakan rumus Slovin (dikutip oleh Umar, 2003) yaitu:

Teknik pengambilan sampel yang di gunakan dalam penelitian ini adalah melalui non probability sampling dengan metoden accidental sampling yaitu mereka yang dijumpai peneliti ditempat penelitian.

Berdasarkan teknik tersebut, maka jumlah sampel yang dapat digunakan dalam penelitian ini adalah 72,75 orang karyawan atau dibulatkan menjadi 73 orang karyawan yang menjadi sampel dengan karakteristik umur 20-45 tahun, pendiidikan maksimal SMA Sederajat, dan lain sebagainya.

\section{Teknik Analisis Data \\ Uji Validitas}

Menurut Sugiyono (2012:121), suatu instrumen dikatakan valid apabila mampu mengukur apa yang diinginkan serta dapat mengungkapkan data yang terkumpul tidak boleh menyeleweng dari deskripsi variabel yang ditafsir. Untuk ketentuan minimum dianggap erat jika $\mathrm{r}$ itu $=0,30$. Bila dikorelasikan antara butir dan skor total mengalami $<0,30$ maka butir diatas akan dinyatakan tidak valid.

\section{Uji Reliabilitas}

Menurut Sugiyono (2012:190), uji Reliabilitas merupakan alat untuk mengukur suatu angket yang merupakan indikator dari variabel atau konstruk. Secara umum uji realibilitas didefinisikan sebagai rangkaian uji lanjutan untuk menilai kehandalan dari item-item pertanyaan yang valid yang dilihat dari nilai Cronbach Alpha $(\alpha)$ yang diperoleh dari $>0.60$

\section{Uji Deskriptif}

Analisis deskriptif mampu dilakukan dengan cara menggunakan tabel frekuensi untuk melihat penyaluran data dalam suatu faktor. Analisis deskriptif ini berguna untuk melihat gambar baik rata-rata maupun penyebaran dari hasil yang telah diperoleh oleh angket, kriteria jawaban responden untuk TCR adalah sebagai berikut :

1. Jika TCR berkisar antara $0 \%$ sampai dengan $54,9 \%$ berarti tidak baik.

2. Jika TCR berkisar antara $55 \%$ sampai dengan $64,9 \%$ berarti kurang baik.

3. Jika TCR berkisar antara $65 \%$ sampai dengan 79,9\% berarti Ragu-ragu.

4. Jika TCR berkisar antara $80 \%$ sampai dengan $89,9 \%$ berarti baik.

5. Jika TCR berkisar antara $90 \%$ sampai dengan $100 \%$ berarti sangat baik

\section{Asumsi Klasik}

\section{Uji Normalitas}

Menurut Ghozali (2008) uji normalitas yakni uji yang dipakai untuk melihat apakah dalam regresi variabel dependen dan variabel independen atau keduanya memiliki pembagian normal atau tidak normal. Data dapat dikatakan terdistribusi normal apabila data memegang nilai asymp signifikan besar alpha 0,05 .

\section{Uji Heteroskedastisitas}

Menurut Ghozali tahun 2008 bahwa uji heteroskedastisitas berfungsi untuk menguji apakah dalam tipe regresi ini mengalami ketidaksamaan versi residual satu pemantauan ke pemantauan lain. Dalam uji ini apabila bila signifikansi > 0,05 atau tidak terjadi problem heteroskedastisitas dan apabila kecil dari 0,05, maka akan terjadi problem heteroskedastisitas dengan bentuk yang bagus yaitu tidak mengalami heteroskedastisitas Ghozali, tahun 2008.

\section{Uji Multikolonieritas}

Menurut dari penelitian Ghozali tahun 2008, yakni untuk mengetahui apakah ada atau tidaknya multikolinearitas dari nilai Tolerance dan Variance Inflation Factor (VIF) serta Nilai tolerance yang biasanya digunaan ialah $>0,10$ atau nilai 
dari VIF $<10$ serta memperlihat tidak terjadinya multikolinearitas.

\section{Analisis Regresi Linear Berganda}

Analisi regresi linear berganda berfungsi untuk mengukur kekuatan hubungan antara variabel Stres Kerja $\left(\mathrm{X}_{1}\right)$, Kepuasan Karyawan $\left(\mathrm{X}_{2}\right)$ terhadap Kinerja Karyawan (Y). Adapun model hubungan antar variabel dapat disusun dalam persamaan dibawah ini :

$\mathrm{Y}=\mathrm{a}+\mathrm{b}_{1} \mathrm{x}_{1}+\mathrm{b}_{2} \mathrm{x}_{2}+\mathrm{e}$

Keterangan :

$\mathrm{a}=$ konstanta

$\mathrm{b}_{1}=$ koefisien regresi dari Stres Kerja

$b_{1}=$ koefisien regresi dari Kepuasan Karyawan

$\mathrm{X}_{1}=$ Stres Kerja

$\mathrm{X}_{2}=$ Kepuasan Kerja

$\mathrm{Y}=$ Kinerja Karyawan

$\mathrm{e}=$ Standar error

Uji t

Untuk menguji kebenaran hipotesis Menurut penelitian Sugiyono pada tahun 2012:184 digunakan yakni untuk mengetahui pengaruh dari tiap-tiap variabel, baik itu variabel bebas maupun variabel terikat yang relevan sesuai dengan data. Dasar pengambilan keputusan dilakukan dengan kriteria angka probabilitas signifikan sebagai berikut :

a. Jika probabilitas $\mathrm{t}>0,05$ maka Ho diterima dan Ha ditolak.

b. Jika probabilitas $\mathrm{t}<0,05$ maka Ho ditolak dan Ha diterima.

\section{Uji F}

Menurut Sugiyono (2012:275), uji koefisien regresi simultan bertujuan untuk mengetahui apakah perumusan model sudah tepat atau fit, hasil $F_{\text {hitung }}>$ dari $F_{\text {tabel }}$ maka model yang dirumuskan sudah tepat. Adapun dasar kriteria pengambilan keputusannya yaitu melalui angka probabilitas signifikan sebagai berikut :

a. Jika probabilitas $F>0,05$ maka Ho diterima dan Ha ditolak

b. Jika probabilitas $\mathrm{F}<0,05$ maka Ho ditolak dan Ha diterima.

\section{Uji Koefisien Determinasi}

Koefisien determinasi bertujuan untuk mengetahui kemampuan variabel independen menjelaskan variabel dependen. Untuk regresi linier berganda sebaiknya menggunakan $R$ Square yang sudah disesuaikan atau tertulis Adjusted $R$ Square, karena disesuaikan dengan jumlah variabel independen yang digunakan dalam penelitian. (Nugroho, 2005:50).

\section{HASIL PENELITIAN DAN \\ PEMBAHASAN \\ Hasil Uji Deskriptif}

Berdasarkan Tabel 4.9 dapat diketahui bahwa sebagian besar responden memberikan penilaian terhadap variabel stres kerja untuk menentukan kinerja karyawan PT. Primatama Mulia Jaya IV Koto Kecamatan Kinali Kab. Pasaman Barat terlihat pada penilaian tertinggi terdapat pada pernyataan No. 7 , yaitu saya sering mengalami pusing ketika mendapatkan beban kerja yang berlebihan dengan nilai TCR sebesar $77,2 \%$ dengan kategori ragu-ragu. Berdasarkan penilaian tertinggi tersebut dapat disimpulkan bahwa karyawan sering mengalami pusing ketika mendapatkan beban kerja yang berlebihan, kejadian tersebut akan memberikan dampak yang buruk terhadap kinerja yang dihasilkan oleh karyawan. Seharusnya pimpinan jangan terlalu berlebihan dalam memberikan beban kerja kepada karyawan karena akan menghasilkan kinerja yang kurang efektif.

Selanjutnya penilaian terendah pada variabel stres kerja terdapat pada pernyataan No. 8, yaitu dengan pekerjaan yang berlebihan dari biasanya membuat saya susah tidur dengan nilai TCR sebesar $71,8 \%$ dengan kategori ragu-ragu. Berdasarkan penilaian terendah tersebut dapat disimpulkan bahwa dengan adanya beban kerja yang berlebihan akan membuat karyawan susah tidur karena karyawan tersebut akan kepikiran secara terus menurus untuk menyelesaikan pekerjaan yang diberikan. Dengan kurangnya istirahat maka fisik karyawan akan menurun sehingga kinerja yang dihasilkan kurang optimal.

Berdasarkan Tabel 4.10 dapat diketahui bahwa sebagian besar responden memberikan penilaian terhadap variabel kepuasan kerja untuk menentukan kinerja karyawan PT. Primatama Mulia Jaya IV Koto Kecamatan Kinali Kab. Pasaman Barat terlihat pada penilaian tertinggi terdapat pada pernyataan No. 5, yaitu saya 
akan tetap bertahan diperusahaan ini karena memberikan fasilitas yang lengkap dengan nilai TCR sebesar $80,4 \%$ dengan kategori ragu-ragu. Berdasarkan penilaian tertinggi tersebut dapat disimpulkan bahwa kepuasan kerja karyawan PT. Primatama Mulia Jaya IV Koto Kecamatan Kinali Kab. Pasaman Barat disebabkan karena fasilitas yang diberikan oleh perusahaan, dengan adanya fasilitas yang lengkap maka dapat menunjang aktifitas karyawan dalam bekerja sehingga dalam bekerja dapat mengasilkan kinerja yang lebih optimal.

Selanjutnya penilaian terendah pada variabel kepuasan kerja terdapat pada pernyataan No. 9, pimpinan memberikan kesempatan kepada setiap karyawanya untuk promosi jabatan dengan nilai TCR sebesar $61,6 \%$ dengan kategori kurang baik. Berdasarkan penilaian terendah tersebut dapat disimpulkan bahwa karyawan kurang puas berkerja di PT. Primatama Mulia Jaya IV Koto Kecamatan Kinali Kab. Pasaman Barat, karena tidak memberikan kesempatan kepada setiap karyawan untuk promosi jabatan, dengan ketidakpuasan karyawan tersebut maka karyawan akan berusaha untuk pindah keperusahaan lain, demi terpenuhinya kebutuhan yang diinginkan. Dengan tindakan karyawan tersebut akan memberikan dampak yang buruk terhadap perusahaan karena perusahaan akan melakukan rekrutmen kembali dan akan mengelurkan biaya yang besar, hal inilah yang membuat profit perusahaan menjadi menurun. Seharusnya perusahaan memberikan kepuasan kerja yang baik kepada karyawan seperti memberikan promosi jabatan kepada setiap karyawan, serta memberikan tunjangan-tunjangan yang dapat membuat karyawan merasa puas bekerja diperusahaan tersebut.

Berdasarkan Tabel dapat diketahui bahwa sebagian besar responden memberikan penilaian terhadap variabel kinerja karyawan PT. Primatama Mulia Jaya IV Koto Kecamatan Kinali Kab. Pasaman Barat terlihat pada penilaian tertinggi terdapat pada pernyataan No. 9, yaitu saya menyelesaikan pekerjaan yang diberikan tepat waktu dengan nilai TCR sebesar $80,6 \%$ dengan kategori baik.
Berdasarkan penilaian tertinggi tersebut dapat disimpulkan karyawan PT. Primatama Mulia Jaya IV Koto Kecamatan Kinali Kab. Pasaman Barat dapat menyelesaikan tepat pada waktunya, hal ini akan memberikan nilai positif terhadap perusahaan, sehingga tujuan yang diinginkan perusahaan dapat tercapai dengan baik. Suatu hal yang harus diperhatikan oleh seorang pimpinan yaitu memberikan beban kerja yang pantas bagi seorang karyawan agar karyawan tersebut tidak mengalami stres dalam melaksanakan pekerjaan serta pekerjaan yang diberikanpun dapat diselesaikan tepat pada waktunya.

Selanjutnya penyebab terendah pada variabel kinerja karyawan PT. Primatama Mulia Jaya IV Koto Kecamatan Kinali Kab. Pasaman Barat terdapat pada pernyataan No. 2, yaitu saya menyelesaikan pekerjaan sesuai dengan target yang diberikan pimpinan dengan nilai TCR sebesar 70,6\% dengan kategori ragu-ragu. Berdasarkan penilaian terendah tersebut dapat disimpulkan bahwa sebagian karyawan PT. Primatama Mulia Jaya IV Koto Kecamatan Kinali Kab. Pasaman Barat belum dapat menyelesaikan pekerjaan sesuai dengan target yang diberikan. Dengan dengan tidak selesainya pekerjaan tepat pada waktunya membuat pekerjaan semakin menumpuk, tujuan yang diinginkan perusahaan belum dapat tercapai dengan optimal. Suatu hal yang harus diperhatikan oleh perusahaan supaya karyawan dapat menyelesaikan pekerjaan tepat pada waktunya yaitu memberikan beban kerja sesuai dengan kemampuan karyawan agar pekerjaan dapat diselesaikan tepat pada waktunya.

\section{Uji Asumsi Klasik}

\section{Uji Normalitas}

Berdasarkan hasil penelitian uji normalitas pada Tabel 1 adalah sebagai berikut ini: 
Tabel 4.12

digunakan dalam penelitian ini tidak

Uji Normalitas

\begin{tabular}{|c|l|c|c|}
\hline No. & Variabel & $\begin{array}{c}\text { Asymp. } \\
\text { Sig. (2- } \\
\text { tailed) }\end{array}$ & Keterangan \\
\hline 1 & Stres Kerja & 0,143 & Distribusi Normal \\
\hline 2 & $\begin{array}{l}\text { Kepuasan } \\
\text { Kerja }\end{array}$ & 0,854 & Distribusi Normal \\
\hline 3 & $\begin{array}{l}\text { Kinerja } \\
\text { Karyawan }\end{array}$ & 0,571 & Distribusi Normal \\
\hline
\end{tabular}

mengandung gangguan multikolinieritas.

Sumber: Data primer yang diolah, 2017

Berdasarkan pada Tabel 4.12 hasil uji normalitas yang dilakukan di atas stres kerja, kepuasan kerja dan kinerja karyawan terlihat bahwa data yang ada telah terdistribusi dengan normal karena nilai signifikan ketiga variabel lebih besar dari 0,05 .

\section{Uji Heteroskedastisitas}

Berdasarkan hasil penelitian uji heterokedasitisitas pada Tabel 4.13 adalah sebagai berikut ini:

Tabel 4.13

Uji Heterokedasitisitas

\begin{tabular}{|c|l|c|c|}
\hline No. & Variabel & Sig & Keterangan \\
\hline 1 & Stres Kerja & 0,918 & $\begin{array}{c}\text { Tidak Terjadi Gejala } \\
\text { Heterokesdatisitas }\end{array}$ \\
\hline 2 & $\begin{array}{l}\text { Kepuasan } \\
\text { Kerja }\end{array}$ & 0,123 & $\begin{array}{l}\text { Tidak Terjadi Gejala } \\
\text { Heterokesdatisitas }\end{array}$ \\
\hline
\end{tabular}

Sumber: Data primer yang diolah, 2017

Berdasarkan pada Tabel 4.13 dapat diketahui bahwa nilai signifikan variabel stres kerja, kepuasan kerja memiliki nilai signifikan > 0,05, hal ini berarti tidak terjadi gejala heterokesdatisitas.

\section{Uji Multikolonieritas}

Berdasarkan hasil penelitian uji multikolonieritas pada Tabel 4.14 adalah sebagai berikut ini:

Tabel 4.14

Uji Multi Kolinearitas

\begin{tabular}{|c|c|c|c|c|}
\hline \multirow[b]{2}{*}{ No. } & \multirow{2}{*}{ Variabel } & \multicolumn{2}{|c|}{ Collinearity Statistics } & \multirow{2}{*}{$\begin{array}{r}\text { kepuasan kerja }\left(\mathrm{X}_{2}\right) \text { dan konstanta }(\mathrm{a}) \\
\text { Keterangahdalah } 0(\mathrm{nol}) \text {, maka kinerja karyawan }\end{array}$} \\
\hline & & Tolerance & VIF & \\
\hline 1 & Stres & 0,895 & 1,11 & Mulia Jaya IV \\
\hline & Kerja & & 8 & Multikolinieritas $\mathrm{Ke}$ \\
\hline 2 & $\begin{array}{l}\text { Kepuasa } \\
\text { n Kerja }\end{array}$ & 0,895 & $\begin{array}{c}1,11 \\
8\end{array}$ & $\begin{array}{l}\text { Tidak Terjadi } \mathrm{m} \\
\text { Multikolinieritas }\end{array}$ \\
\hline
\end{tabular}

Sumber: Data primer yang diolah, 2017

Berdasarkan Tabel 4.14 di atas dapat diketahui bahwa tolerance value untuk masing-masing variabel lebih besar dari 0,10 sedangkan nilai Variance Inflation Factor (VIF) untuk masingmasing variabel lebih kecil dari 10. Dengan demikian dapat disimpulkan model yang
Uji Regresi Linear Berganda

Berdasarkan uji regresi berganda yang dilakukan dapat dilihat pada Tabel 15 di bawah ini:

Tabel. 4.15

Hasil Uji Regresi Linear Berganda Coefficients $^{\mathrm{a}}$

\begin{tabular}{|c|c|c|c|c|c|}
\hline \multirow[b]{2}{*}{ Model } & \multicolumn{2}{|c|}{$\begin{array}{l}\text { Unstandardized } \\
\text { Coefficients }\end{array}$} & $\begin{array}{l}\text { Standardized } \\
\text { Coefficients }\end{array}$ & \multirow[b]{2}{*}{$\mathrm{T}$} & \multirow[b]{2}{*}{ Sig. } \\
\hline & B & Std. Error & Beta & & \\
\hline $1 \quad$ (Constant) & 18,776 & 4,512 & & 4,162 & 0,000 \\
\hline Stres_Kerja & 0,510 & 0,097 & 0,521 & 5,262 & 0,000 \\
\hline Kepuasan_Kerja & 0,156 & 0,074 & 0,210 & 2,117 & 0,038 \\
\hline
\end{tabular}

a. Dependent Variable: Kinerja_Karyawan

Berdasarkan analisis data dengan menggunakan program SPSS 20 for windows, maka diperoleh hasil persamaan regresi sebagai berikut:

$$
\begin{gathered}
\mathrm{Y}=18,776+0,510 \mathrm{X}_{1}+0,156 \mathrm{X}_{2}+\mathrm{e} \\
\text { Persamaan regresi di atas }
\end{gathered}
$$
memperlihatkan hubungan antara variabel independen dengan variabel dependen secara parsial, dari persamaan tersebut dapat diambil kesimpulan bahwa :

1) Nilai constanta adalah $=18,776$ artinya jika tidak terjadi perubahan variabel stres kerja dan kepuasan kerja (nilai $\mathrm{X}_{1}$ dan $\mathrm{X}_{2}$ adalah 0) maka kinerja karyawan pada Primatama Mulia Jaya IV Koto Kecamatan Kinali Kab. Pasaman Barat tetap sebesar 18,776 satuan.

2) Nilai koefisien regresi stres kerja adalah $=0,510$ artinya jika variabel stres kerja $\left(\mathrm{X}_{1}\right)$ meningkat sebesar 1 (satuan) dengan asumsi variabel kepuasan kerja $\left(\mathrm{X}_{2}\right)$ dan konstanta (a) Nilai koefisien regresi kepuasan kerja adalah $=0,156$ artinya jika variabel kepuasan kerja $\left(\mathrm{X}_{2}\right)$ meningkat sebesar 1 (satuan) dengan asumsi variabel stres kerja $\left(\mathrm{X}_{1}\right)$ dan konstanta (a) adalah 0 (nol), maka kinerja karyawan Primatama Mulia Jaya IV Koto Kecamatan Kinali Kab. Pasaman Barat meningkat sebesar 0,156 satuan. 


\section{Uji Hipotesis}

Uji t

Berdasarkan uji $\mathrm{t}$ yang dilakukan dapat dilihat pada Tabel 4.16 di bawah ini:

Tabel 4.16

Hasil Uji t

Coefficients $^{\mathrm{a}}$

\begin{tabular}{|ll|r|r|r|}
\hline \multirow{2}{*}{ Model } & \multicolumn{2}{|c|}{$\begin{array}{c}\text { Unstandardized } \\
\text { Coefficients }\end{array}$} & $\begin{array}{c}\text { Standardized } \\
\text { Coefficients }\end{array}$ \\
\cline { 2 - 5 } & \multicolumn{1}{c|}{ B } & Std. Error & \multicolumn{1}{c|}{ Beta } \\
\hline $1 \quad$ (Constant) & 18,776 & 4,512 & \\
& Stres_Kerja & 0,510 & 0,097 & 0,521 \\
& Kepuasan_Kerja & 0,156 & 0,074 & 0,210 \\
\hline
\end{tabular}

a. Dependent Variable: Kinerja_Karyawan

Sumber : Data primer yang diolah, 2017

Variabel stres kerja $\left(\mathrm{X}_{1}\right)$ berpengaruh secara positif dan signifikan terhadap kinerja karyawan PT. Primatama Mulia Jaya IV Koto Kecamatan Kinali Kab. Pasaman Barat dengan nilai $\mathrm{t}_{\text {hitung }}$ sebesar 5,262 sedangkan nilai signifikan $<0,05$, maka Ho ditolak dan $\mathrm{H}_{1}$ diterima.

Variabel kepuasan kerja $\left(\mathrm{X}_{2}\right)$ berpengaruh secara positif dan signifikan terhadap kinerja karyawan PT. Primatama Mulia Jaya IV Koto Kecamatan Kinali dengan nilai $t_{\text {hitung }}$ sebesar 2,117 sedangkan nilai signifikan $<0,05$, maka Ho ditolak dan $\mathrm{H}_{2}$ diterima.

\section{Uji F}

Berdasarkan uji $\mathrm{F}$ yang dilakukan dapat dilihat pada Tabel 4.17 di bawah ini:

Tabel 4.17

Hasil Uji F

ANOVA $^{b}$

\begin{tabular}{|c|c|c|c|c|}
\hline Model & $\begin{array}{l}\text { Sum of } \\
\text { Squares }\end{array}$ & $\mathrm{df}$ & $\begin{array}{l}\text { Mean } \\
\text { Square }\end{array}$ & $\mathrm{F}$ \\
\hline 1 Regression & 875,747 & 2 & 437,874 & 22,027 \\
\hline Residual & 1391,513 & 70 & 19,879 & \\
\hline Total & 2267,260 & 72 & & \\
\hline
\end{tabular}

a. Predictors: (Constant), Kepuasan_Kerja, Stres_Kerja

b. Dependent Variable: Kinerja_Karyawan

Berdasarkan hasil pengujian pada tabel di atas dapat dilihat pada nilai $F$ hitung sebesar 22,027 dengan nilai signifikan < 0,05 maka $\mathrm{Ho}$ ditolak dan $\mathrm{H}_{3}$ diterima. Sehingga dapat disimpulkan bahwa variabel stres kerja $\left(\mathrm{X}_{1}\right)$ dan kepuasan kerja $\left(\mathrm{X}_{2}\right)$ secara bersamaan berpengaruh signifikan terhadap kinerja karyawan PT.
Primatama Mulia Jaya IV Koto Kecamatan

Kinali Kab. Pasaman Barat.

Uji Koefisien Determinasi

Berdasarkan uji koefisien determinasi yang dilakukan maka dapat dilihat pada Tabel 4.18 berikut ini:

Tabel 4.18

Hasil Uji Koefisien Determinasi Model Summary

\begin{tabular}{|c|c|c|c|c|}
\hline \multirow[b]{2}{*}{ Model } & \multirow[b]{2}{*}{$\begin{array}{l}\text { Adjusted } \\
\text { R Square }\end{array}$} & \multicolumn{3}{|c|}{ Change Statistics } \\
\hline & & $\begin{array}{l}\text { R Square } \\
\text { Change }\end{array}$ & F Change & Sig. F Change \\
\hline 1 & 0,369 & ,386 & 22,027 & 0,000 \\
\hline
\end{tabular}

Berdasarkan Tabel 4.12 dapat diketahui bahwa nilai koefisien determinasi terdapat pada nilai Adjusted $R$ Square dengan sebesar 0,369. Hal ini berarti kontribusi variabel bebas dalam menjelaskan variabel terikat adalah sebesar $36,9 \%$ sisanya $63,1 \%$ dijelaskan oleh variabel lain yang tidak dibahas dalam penelitian ini.

\section{Pembahasan Hasil Penelitian}

Berdasarkan analisa data mengenai pengaruh variabel stres kerja $\left(\mathrm{X}_{1}\right)$ dan variabel kepuasan kerja $\left(\mathrm{X}_{2}\right)$ serta secara individu dan secara bersamaan terhadap kinerja karyawan Primatama Mulia Jaya IV Koto Kecamatan Kinali Kab. Pasaman Barat, maka pembahasan hasilnya adalah sebagai berikut:

1) Pengaruh Variabel Stres Kerja Terhadap Kinerja Karyawan.

Dari hasil analisis uji hipotesa pada पingkat hepercayaan $\alpha=5 \%$ terbukti bahwa variabel stres kerja $\left(\mathrm{X}_{1}\right)$ berpengaruh positif dan,oskg ifikan terhadap kinerja karyawan PT. Pr matama Mulia Jaya IV Koto Kecama an Kinali Kab. Pasaman Barat hilai $t_{\text {hitung }}$ sebesar 5,262 sedangkan nilai signifikan $<0,05$.

Berdasarkan hasil penelitian tersebut dapat disimpulkan bahwa kinerja karyawan PT. Primatama Mulia Jaya IV Koto Kecamatan Kinali Kab. Pasaman Barat di sebabkan beberapa faktor seperti aspek pisikologis, aspek fisik dan aspek perilaku, dari beberapa faktor tersebut yang paling dominan mempengaruhi kinerja karyawan PT. Primatama Mulia Jaya IV Koto Kecamatan Kinali Kab. Pasaman Barat 
adalah aspek psikologis, dengan tingginya stres kerja yang terjadi pada karyawan maka karyawan tersebut akan lebih mudah tersingsung, stres kerja yang tinggi tidak bisa berfikir lebih komunikatif, sering melamun dan beban kerja yang berat membuat karyawan banyak berfikir sehingga membuat lelah mental. Faktor inilah yang perlu diperhatikan oleh seorang pimpinan dalam memberikan beban kerja kepada seorang karyawan agar karyawan tersebut tidak melangalami stres pada saat melaksanakan pekerjaan, jika stres kerja karyawan meningkat maka kinerja yang dihasilkan tidak akan optimal.

\section{2) Pengaruh Variabel Kepuasan Kerja Terhadap Kinerja Karyawan.}

Dari hasil analisis uji hipotesa pada tingkat kepercayaan $\alpha=5 \%$ terbukti bahwa variabel kepuasan kerja $\left(\mathrm{X}_{2}\right)$ berpengaruh positif dan signifikan terhadap kinerja karyawan PT. Primatama Mulia Jaya IV Koto Kecamatan Kinali Kab. Pasaman Barat dengan nilai $t_{\text {hitung }}$ sebesar 2,117 sedangkan nilai signifikan $<0,05$.

Berdasarkan hasil tersebut dapat disimpulkan bahwa kinerja karyawan disebabkan karena kepuasan kerja yang ada pada diri karyawan karena dengan adanya kepuasan tersebut maka karyawan akan berusaha untuk mengoptimalkan hasil kinerja hal ini disebabkan oleh beberapa faktor diantaranya pekerjaan itu sendiri, gaji, kesempatan atau promosi, pengawasan atau supervise dan rekan kerja, dari beberapa faktor tersebut yang paling dominan mempengaruhi kinerja karyawan adalah gaji, karena dengan adanya gaji yang memadai maka karyawan merasa puas bekerja diperusahaan tersebut sehingga karyawan akan berusaha untuk bekerja lebih baik demi kemajuan perusahaan tempat mereka bekerja.

\section{3) Pengaruh Variabel Stres Kerja dan Kepuasan Kerja Terhadap Kinerja Kerja. \\ Dari hasil uji $F$ terbukti bahwa} variabel stres kerja $\left(\mathrm{X}_{1}\right)$ dan kepuasan kerja $\left(\mathrm{X}_{2}\right)$ secara bersama-sama mempunyai pengaruh yang positif dan signifikan terhadap kinerja karyawan PT. Primatama Mulia Jaya IV Koto Kecamatan Kinali Kab. Pasaman Barat, hal ini dapat di buktikan dengan nilai $\mathrm{F}_{\text {hitung }}$ sebesar 22,027 dan nilai signifikan < 0,05 , sehingga dapat disimpulkan bahwa variabel stres kerja $\left(\mathrm{X}_{1}\right)$ dan kepuasan kerja $\left(\mathrm{X}_{2}\right)$ secara bersamaan berpengaruh signifikan terhadap kinerja karyawan PT. Primatama Mulia Jaya IV Koto Kecamatan Kinali Kab. Pasaman Barat sebesar 36,9\% sisanya $63,1 \%$ dijelaskan oleh variabel lain yang tidak dibahas dalam penelitian ini.

Berdasarkan hasil tersebut dapat disimpulkan bahwa kinerja karyawan PT. Primatama Mulia Jaya IV Koto Kecamatan Kinali Kab. Pasaman Barat dipengaruhi oleh stres kerja dan kepuasan kerja. Dari kedua variabel tersebut yang paling dominan mempengaruhi kinerja karyawan PT. Primatama Mulia Jaya IV Koto Kecamatan Kinali Kab. Pasaman Barat adalah stres kerja, karena semakin tinggi stres kerja seorang karyawan dalam bekerja maka karyawan tersebut merasa jenuh dalam menyelesaikan pekerjaan, sehingga tujuan yang diinginkan perusahaan belum tercapai dengan baik, sebaiknya pimpinan memberikan beban kerja sesuai dengan kemampuan seorang karyawan agar karyawan tersebut tidak mengalami stres dalam menjalankan pekerjaan sehingga kinerja yang dihasilkan sesuai dengan yang diharapkan.

\section{KESIMPULAN DAN SARAN \\ Kesimpulan}

Berdasarkan penelitian yang telah dilakukan, maka dapat ditarik kesimpulan bahwa:

1. Variabel stres kerja berpengaruh secara positif dan signifikan terhadap kinerja karyawan PT. Primatama Mulia Jaya IV Koto Kecamatan Kinali Kab. Pasaman Barat dengan nilai $t_{\text {hitung }}$ sebesar 5,262 sedangkan nilai signifikan $<0,05$.

2. Variabel kepuasan kerja berpengaruh secara positif dan signifikan terhadap kinerja karyawan PT. Primatama Mulia Jaya IV Koto Kecamatan Kinali Kab. Pasaman Barat dengan nilai $t_{\text {hitung }}$ sebesar 2,117 sedangkan nilai signifikan $<0,05$.

3. Secara bersamaan bahwa terdapat pengaruh yang positif dan signifikan antara variabel stres kerja dan 
kepuasan kerja terhadap kinerja Ardisasmita, Rahardjo, 2005. Dasar-dasar karyawan PT. Primatama Mulia Jaya IV Koto Kecamatan Kinali Kab. Pasaman Barat, hal ini dapat di buktikan dengan nilai $\mathrm{F}_{\text {hitung }}$ sebesar 22,027 dan nilai signifikan $<0,05$. Sedangkan nilai Adjusted $R$ Square dengan sebesar 0,369 . Hal ini berarti kontribusi variabel bebas dalam menjelaskan variabel terikat adalah sebesar $\quad 36,9 \%$ sisanya $63,1 \%$ dijelaskan oleh variabel lain yang tidak Saran dibahas dalam penelitian ini.

Hasil penelitian ini memberikan wawasan kepada peneliti dan perusahaan yang diteliti. Penulis mencoba memberikan sumbangan pemikiran sebagai berikut:

1. Sebaiknya dalam meningkatkan kinerja karyawan pimpinan seharusnya jangan terlalu berlebihan dalam memberikan beban kerja kepada karyawan karena akan menghasilkan kinerja yang kurang efektif.

2. Sebaiknya dalam meningkatkan kinerja karyawan seharusnya perusahaan memberikan kepuasan kerja yang baik kepada karyawan seperti memberikan gaji yang sesuai jam kerja, serta memberikan tunjangan-tunjangan yang dapat membuat karyawan merasa puas bekerja diperusahaan tersebut.

3. Bagi peneliti selanjutnya penulis menyarankan, agar memperbanyak jumlah responden yang akan digunakan, serta dilakukan dengan rentang waktu yang lebih lama. Hal ini perlu dilakukan agar hasil yang ditemukan dalam penelitian tersebut akan lebih baik dari penelitian ini.

\section{DAFTAR PUSTAKA}

Agung Nugroho, 2005. Strategi Jitu Memilih Metode Statistic Penelitian Dengan SPSS, Andi Jogyakarta. Ardisasmita, Rahardjo, 2005. Dasar-dasar Ekonomi Wilayah. Yogyakarta: Graha Ilmu.

Ekonomi Wilayah. Yogyakarta: Graha Ilmu.

Arikunto, S. 2010. Prosedur Penelitian : Suatu Pendekatan Praktik. (Edisi Revisi). Jakarta : Rineka Cipta.

Augusty, Ferdinand. 2006. Metode Penelitian Manajemen. Semarang : Badan Penerbit Universitas Diponegoro.

A.A. Anwar Prabu Mangkunegara. 2001, Manajemen Sumber Daya Manusia Perusahaan, Bandung : Remaja Rosdakarya.

Dhania, R. D. (2010). Pengaruh Stres Kerja, Beban Kerja Terhadap Kepuasan Kerja (Studi Pada Medical Representatif Di Kota Kudus). Jurnal Psikologi Vol 1, No 1 2010. Kudus: Universitas Muria Kudus.

Dona, E. (2018). Analisis Motivasi

Kerja Ditinjau Dari

Lingkungan Kerja Kasus

Karyawan LBPP Lia

Payakumbuh. Jurnal KBP.

Edi Sutrisno. 2012. Pengaruh Stres Kerja

Terhadap Kinerja Karyawan Pada Madrasah Aliyah Negeri Demak. Digilib.uin-suka.ac.id/11585/

Gaffar, Hulaifah. 2012. Pengaruh Stres Kerja Terhadap Kinerja Karyawan Pada PT. Bank Mandiri (Persero) Tbk. Kantor Wilayah X Makassar. Makassar: Universitas Hasanuddin.

Ghozali, Imam. 2005. Aplikasi Analisis Multivariate Dengan Program SPSS ; Pendekatan Terintegrasi. Semarang: Badan Penerbit Universitas Diponegoro.

Hasibuan, Melayu. 2006. Manajemen Sumber Daya Manusia, Bumi Aksara:Jakarta.

Hasan, M. Iqbal, Pokok-Pokok Materi Metodologi Penelitian dan Aplikasinya, Ghalia Indonesia, Bogor, 2002.

Henry Simamora. 2004. Manajemen Sumber Daya Manusia. Edisi ke3. STIE YKPN.Yogyakarta. 
Husein Umar, 2005. Metode Penelitian. Jakarta : Salemba Empat

Luthans, Fred. 2006. Perilaku Organisasi, (Alih Bahasa V.A Yuwono, dkk), Edisi Bahasa Indonesia, Yogyakarta: ANDI

Marlius, D. RD Putra. (2018). Strategi Pengembangan Sulam Bayang. Jurnal Benefita: Ekonomi Pembangunan Manajemen Bisnis Dan Akuntansi. Volume 3. No. 2. Hal. 204-218. http://doi.org/10.22216/jbe.v3i 2.3494

Mayliza, R. (2019). Pengaruh Kompensasi Finansial, Lingkungan Kerja Dan Motivasi Kerja Terhadap Kinerja Pegawai Pada Kantor PDAM Kota Payakumbuh. https://doi.org/10.17605/OSF.I O/DZXAF

Mayliza, R. (2019). Pengaruh Gaya Kepemimpinan Dan Disiplin Kerja Terhadap Kinerja Karyawan Dengan Motivasi Kerja Sebagai Variabel Intervening Pada PT. Semen Padang. https://doi.org/10.17605/OSF.I O/FYPQ9.

Mayliza, R. (2019). Pengaruh Konflik Dan Kejenuhan Terhadap Kepuasan Kerja Karyawan PT. PLN (Persero) Sektor Pembangkitan Dan Pengendalian Pembangkitan Ombilin.

https://doi.org/10.17605/OSF.I O/DQZ3K

Mayliza, R. (2019). Kontribusi Sistem Penghargaan Dan Lingkungan Kerja Terhadap Efektifitas Kerja Pegawai Pada Kantor Dinas Pendidikan Kota Padang. https://doi.org/10.17605/OSF.I O/VWZH3
Mayliza, R. (2019). Pengaruh Gaya Kepemimpinan Dan Disiplin Kerja Terhadap Kinerja Pegawai, Dengan Motivasi Kerja Sebagai Variabel Intervening (Studi Pada Dinas Pendidikan Kabupaten Tanah Datar). https://doi.org/10.17605/OSF.I O/JGPDN

Munandar Ashar Sunyoto, 2001. Psikologi Industri Dan Organisasi. Jakarta: Universitas Indonesia.

Munandar, M. 2001. Budgeting, Perencanaan Kerja Pengkoordinasian Kerja Pengawasan Kerja. Edisi Pertama. BPFE Universitas Gajah Mada. Yogyakarta.

Nardo, R. Evanita, Syahrizal, S. (2018). Pengaruh Kepemimpinan Transformasional, Dan Lingkungan Kerja Non Fisik Terhadap Perilaku Inovatif. JEBI (Jurnal Ekonomi dan Bisnis Islam) 3 (2), 209-215

Nardo, R. Evanita, Syahrizal, S. (2019). The Effect of Transformational Leadership and Non Physical Work Environment on Innovative Behavior with Work Motivation as a Mediation For Employees of Tour And Travel Companies In West Sumatera. 2nd Padang International Conference on Education, Economics, Business and Accounting (PICEEBA-2 2018)

Prabu-Mangkunegara, A.A.A. (2005). Perilaku dan Budaya Organisasi. Bandung: PT Refika Aditama.

Putra, RY. Marlius, D. (2019). Pengaruh Pendidikan, Pengalaman Kerja dan Etos Kerja Terhadap Kinerja Pegawai Di KPN Batur. Academic Conference For Management 2. 
Robbins, S.P. (2002). Prinsip-Prinsip Perilaku Organisasi. Edisi Kelima (Terjemahan). Jakarta:Penerbit Erlangga

Robbins, Stephen P. 2003. Essentials Of Organizational Behavior (Terjemahan), Edisi Kelima, Penerbit Erlangga ; Jakarta..

Sugiyono, 2004. Metode Penelitian Bisnis. Bandung : Alfabeta.

Sugiyono, 2005. Metode Penelitian Kuantitatif Kualitatif. Bandung : Alfabeta.

Sugiyono. 2009. Metode Penelitian Kuantitatif dan Kualitatif. CV. Alfabeta:Bandung.

Sugiyono, 2011. Metode Penelitian Kualitatif dan R\&D. Bandung : Alfabeta.

Sugiyono. 2013. Metode Penelitian Pendidikan (Pendekatan Kuantitatif, Kualitatif, dan R\&D). Bandung : Alfabeta.

Sukmadinata, 2006. Metode Penelitian Pendidikan, Remaja Rosdakarya, Bandung.

Susriyanti, S. Nardo, R. (2019). Pengaruh Fungsi Komunikasi Dan Kepuasan Kerja Karyawan Terhadap Pemberian Pelayanan Nasabah PT. BPR LPN Talawi Sakato. Jurnal Administrasi Sosial dan Humaniora 3 (2), 97-111.

Yudistira, D. S., \& Susanti, F. (2019). Pengaruh Motivasi Kerja Dan Budaya Kerja Terhadap Kinerja Karyawan Dinas Pemberdayaan Masyarakat Dan Desa, Pengendalian Penduduk Dan Keluarga Berencana Kabupaten Pesisir Selatan.

https://doi.org/10.31227/osf.io/ $\mathrm{jk} 54 \mathrm{~m}$

Mulyadi, H., \& Susanti, F. (2018). Pengaruh Penerapan Strategi Customer Relationship Marketing Terhadap Kepuasan Nasabah Pada PT. Pro Car
International Finance Cabang Padang.

https://doi.org/10.31227/osf.io/ bhq8d

Ridho, M., \& Susanti, F. (2019). Pengaruh Stres Kerja Dan Motivasi Kerja Terhadap Kepuasan Kerja Pada Karyawan Bank Mandiri Syariah Cabang Padang. https://doi.org/10.31227/osf.io/ pa2cg

Lubis, A. Y. O., \& Susanti, F. (2019). Pengaruh Gaya Kepemimpinan Dan Kompensasi Terhadap Prestasi Kerja Karyawan (Studi pada PT Japfa Comfeed Indonesia (JCI) Tbk Devisi Fam 1. https://doi.org/10.31227/osf.io/ 7tbrg

Jamarnis, S., \& Susanti, F. (2019). Pengaruh Harga Dan Periklanan Melalui Internet Terhadap Keputusan Pembelian Produk Sabun Merek Lux Pada Mahasiswa STIE "KBP" Padang. https://doi.org/10.31227/osf.io/ $\mathrm{xz} 3 \mathrm{~d} 8$

Aldi, Y., \& Susanti, F. (2019). Pengaruh Stress Kerja Dan Motivasi Kerja Terhadap Prestasi Kerja Karyawan Pada PT. Frisian Flag Indonesia Wilayah Padang. https://doi.org/10.31227/osf.io/ et $4 \mathrm{rn}$

Widodo, B. H., \& Susanti, F. (2019). Pengaruh Human Relation (Hubungan Antar Manusia), Lingkungan kerja Terhadap Etos Kerja karyawan (Studi Kasus Pada PT. Pelindo Teluk Bayur Padang ). https://doi.org/10.31227/osf.io/ dxm8a 
Junaidi, R., \& Susanti, F. (2019).

Pengaruh Gaya Kepemimpinan

Dan Budaya Organisasi

Terhadap Kinerja Pegawai

Pada UPTD Baltekkomdik

Dinas Pendidikan Provinsi

Sumatera Barat.

https://doi.org/10.31227/osf.io/

bzq75 